\title{
Test Saliva Check Mutans w ocenie ryzyka próchnicy
}

\author{
Test Saliva Check Mutans for dental caries risk assessment \\ ' Zakład Stomatologii Grup Ryzyka, Katedra Stomatologii Dziecięcej, \\ Uniwersytet Medyczny im. Karola Marcinkowskiego w Poznaniu \\ ${ }^{2}$ Katedra i Klinika Stomatologii Dziecięcej, Uniwersytet Medyczny im. Karola Marcinkowskiego w Poznaniu
}

DOI: http://dx.doi.org/10.20883/df.2020.2

\begin{abstract}
STRESZCZENIE
Celem badania była ocena przydatności testu Saliva Check Mutans w określaniu ryzyka próchnicy zębów. Badanie kliniczne polegało na ocenia stanu uzębienia, stanu higieny jamy ustnej oraz dziąseł dorosłych pacjentów. Ocenę miana Streptococcus mutans w stymulowanej ślinie mieszanej badanych osób wykonano za pomocą testu Saliva Check Mutans. Test Saliva Check Mutans wydaje się być szybkim testem przydatnym w ocenie ryzyka próchnicy zębów, pozwalającym klinicyście na ocenę poziomu drobnoustrojów próchnicotwórczych. Może być on również wykorzystywany w edukacji pacjentów w celu zmotywowania ich do poprawy higieny jamy ustnej.
\end{abstract}

Słowa kluczowe: ocena ryzyka próchnicy, testy bakteriologiczne.

\section{ABSTRACT}

The purpose of the study was to evaluate the usefulness of the Saliva Check Mutans test in dental caries risk assessment. The clinical examination consisted of determining the dental caries experience, oral hygiene level and the gingival status in adult patients. The titre of Streptococcus mutans in the stimulated mixed saliva of the examined persons was assessed using the Saliva Check Mutans test. The Saliva Check Mutans test appears to be a rapid test useful in assessing the risk of dental caries, allowing the clinician to determine the level of cariogenic microorganisms. It can also be used in educating patients to motivate them to improve their oral hygiene.

Keywords: caries risk assesment, bacteriological test.

\section{Wstęp}

Stan zdrowotny jamy ustnej uwarunkowany jest szeregiem czynników genetycznych, biologicznych oraz socjalnych. Najczęściej występującym schorzeniem jamy ustnej, szeroko rozpowszechnionym w społeczeństwie zarówno wśród dzieci, jak i osób dorosłych, jest choroba próchnicowa zębów. Jej rozwój i przebieg, uzależniony przede wszystkim od zachowania równowagi pomiędzy czynnikami chorobotwórczymi a obronnymi gospodarza, zależy od obecności i liczby patogennych mikroorganizmów. Nowoczesne metody prewencyjne polegają przede wszystkim na zindywidualizowanej profilaktyce, zakładającej również ocenę i monitorowanie czynników zagrażających. Jedną z metod klinicznej oceny ryzyka są testy bakteriologiczne, które pozwalają oszacować obecność i miano określonych drobnoustrojów w ślinie pacjenta [1, 2]. Dotychczas stosowane testy (m.in. Dentocult SM Strip mutans czy Dentocult LB (Orion Diagnostica), CRT Bacteria $^{\circledast}$ (Ivoclar-Vivadent)) wymagały zastosowania selektywnego podłoża do hodowli bakterii oraz inkubatorów, przez co uzyskanie szybkiego wyniku nie było możliwe. Obecnie dostępne są szybkie testy immunochromograficzne. Jednym z nich, pozwalającym na szybką ocenę liczby kolonii bakteryjnych Streptococcus mutans w ślinie pacjenta $\mathrm{w}$ ramach wizyty $\mathrm{w}$ gabinecie stomatologicznym, jest test Saliva Check Mutans firmy GC.

\section{Cel}

Celem badania była ocena przydatności testu Saliva Check Mutans w określaniu ryzyka próchnicy u dorosłych pacjentów.

\section{Materiał i metody}

Do badania zostało zakwalifikowanych 10 pacjentek w wieku 20-50 lat, u których w badaniu kli- 
nicznym nie stwierdzono ognisk czynnej próchnicy. Wszystkie pacjentki były ogólnie zdrowe i nie przyjmowały przewlekle żadnych leków oraz w przeciągu ostatnich 3 miesięcy nie przechodziły kuracji antybiotykowej.

Wstępne badanie kliniczne jamy ustnej przeprowadzono w warunkach gabinetu stomatologicznego, przy użyciu lusterka stomatologicznego oraz zgłębnika. Występowanie próchnicy oceniano z użyciem wskaźnika PUWz i PUWp. Poziom higieny jamy ustnej szacowano za pomocą uproszczonego (bez wybarwiania) aproksymalnego wskaźnika płytki nazębnej - API (Aproximal Plaque Index) wg Lange (1986) [3]. Zgodnie z wytycznymi obecność płytki bakteryjnej badano w kwadrantach 1 i 3 na powierzchniach stycznych od strony jamy ustnej właściwej, a w kwadrantach 2 i 4 na powierzchniach stycznych od strony przedsionka. Kryterium oceny było występowanie płytki na powierzchniach stycznych (+) lub jej brak (-). Wartość wskaźnika określa odsetek sumy powierzchni z płytką nazębną w stosunku do sumy wszystkich badanych powierzchni; < 25\% świadczy o optymalnej higienie jamy ustnej, $25-39 \%$ o dostatecznej, $40-69 \%$ o przeciętnej, a > 70\% o złej.

Do oceny stanu dziąseł wykorzystano wskaźnik krwawienia dziąseł - BOP (Bleeding on Probing) wg Ainamo i Bay'a (1975) [4]. Wskaźnik ten polega na stwierdzeniu obecności lub braku prowokowanego krwawienia podczas delikatnego sondowania szczeliny dziąsłowej. Ocenę przeprowadzano przy każdej powierzchni zęba, tj. w 4 punktach pomiarowych. Wynik stanowi odsetek miejsc z krwawieniem w odniesieniu do wszystkich zbadanych powierzchni. Wartość poniżej $10 \%$ świadczy o niskim, powyżej $25 \%$ o wysokim, a pomiędzy 10 a 25 o średnim stanie zapalnym dziąsła [5].

Badanie mikrobiologiczne polegało na ocenie miana S. mutans w stymulowanej ślinie mieszanej uzyskanej od pacjenta. Do stymulacji wydzielania śliny zastosowano, załączoną w teście, kostkę parafinową, którą badany przed pobraniem materiału do badań żuł przez 5 minut. Następnie do uzyskanej wydzieliny dodawano dwa odczynniki wchodzące w skład zestawu, po czym kroplę umieszczono w okienku testowym. Po upływie 15 minut odnotowywano wynik. Pojawienie się wyraźniej czerwonej linii wskazywało wysokie, $>500000$ CFU /ml (CFU - ang. Colony forming units), miano $S$. mutans. Wynik taki świadczył o wysokim ryzyku choroby próchnicowej u danego pacjenta. Natomiast w przypadku, gdy liczba kolonii w badanej wydzielinie nie przekraczała tej granicznej warto- ści, w okienku testowym pojawia się tylko różowy pasek kontrolny.

\section{Wyniki}

Liczba PUWz u badanych osób wynosiła 12,5, a średnia liczba PUWp 26,5. Uzyskana średnia wartość wskaźnika higieny jamy ustnej API (40,5\%) wskazywała na przeciętny jej poziom, a wartość wskaźnika BOP $(6,3 \%)$ na brak objawów zapalenia dziąseł.

We wszystkich pobranych od 10 osób próbkach, obok różowego paska kontrolnego, w okienku testowym zaobserwowano pojawienie się czerwonej kreski, co świadczyło o pozytywnym wyniku testu (S. mutans $\geq 500000 \mathrm{CFU} / \mathrm{ml}$ ).

\section{Dyskusja}

Zależność między fizykochemicznymi właściwościami śliny oraz obciążeniem mikrobiologicznym jamy ustnej a chorobą próchnicową zębów jest dobrze udokumentowana w piśmiennictwie $[6,7]$. Ważnym elementem oceny ryzyka próchnicy zębów jest określenie poziomu bakterii kariogennych. Ze względu na to, że S. Mutans odgrywa kluczową rolę w rozwoju oraz progresji choroby próchnicowej, stanowi on istotny biomarker ryzyka próchnicy [8-10]. W związku z tym oszacowanie jego miana w biofilmie płytki nazębnej i/lub ślinie pozwala przeprowadzić mikrobilogiczną ocenę ryzyka próchnicy oraz monitorować aktywność choroby [10]. Zastosowanie szybkich, immunochromatograficznych, diagnostycznych i komercyjnych testów pozwala na ocenę mikrobiologiczną w przeciągu 15 minut i określenie ryzyka próchnicy w warunkach gabinetu stomatologicznego, bez konieczności wykonywania badań laboratoryjnych $[8,9]$. Prezentowanymi badaniami pilotażowymi objęto niewielką grupę pacjentów.

Test Saliva Check Mutans umożliwia szybką diagnostyką poziomu S. mutans w ślinie pacjenta. Test opiera się na specyficznym procesie immunochromatografii, wykorzystującym unikalną zdolność przeciwciał do wybiórczego wiązania z konkretną cząsteczką (antygenem), którą w tym przypadku jest S. mutans. Przeznaczony jest on do detekcji obecności (lub jej braku) odpowiedniego miana tego drobnoustroju. W teście znajdują się dwa przeciwciała monoklonalne. Zasada działania testu bazuje na metodzie immunologicznej polegającej na łączeniu się przeciwciał $z$ antygenami. Efektem tej reakcji jest uformowanie się kompleksu przeciwciało-antygen, który zostaje wykryty przez test. Interpretacja wyników polega na potwierdzeniu lub wykluczeniu obecności antyge- 
nów w badanej próbce na podstawie obserwacji pojawiających się barwnych pasków. Pojawienie się dwóch kresek - kontrolnej i wynikowej, świadczy o pozytywnym wyniku testu [11]. Dodatni wynik reakcji antygen-przeciwciało oznacza, że u danego pacjenta poziom S. mutans wynosi równo lub powyżej 500000 CFU na 1 ml śliny, co wskazuje na wysokie ryzyko próchnicy [8,9].

Dotychczas niewiele jest doniesień w piśmiennictwie na temat testu Saliva Check Mutans. Wennerholm i Emilson [8] porównywali wyniki badań oceny ryzyka próchnicy zębów u 71 dorosłych osób w wieku 20-73 lat przeprowadzonych za pomocą testu Saliva Check Mutans z wynikami uzyskanymi w oparciu o badania $z$ wykorzystaniem programu komputerowego Cariogram. Uzyskane przez badaczy wyniki wykazały, iż skuteczność obu metod badawczych jest porównywalna [8]. Podobne wyniki uzyskali Saravia i wsp. [12], przeprowadzając badania pośród 93 osób w wieku 1826 lat. Autorzy ci porównywali wyniki uzyskane z zastosowaniem testu Saliva Check Mutans z wynikami badań przeprowadzonych w laboratorium z użyciem mikroskopu stereoskopowego. Uzyskana przez cytowanych autorów zgodność metod badawczych potwierdziła przydatność testu Saliva Check Mutans w ocenie mikrobiologicznej ryzyka próchnicy.

Test Saliva Check Mutans wyróżnia się na tle innych metod $w$ diagnostyce ryzyka próchnicy zębów. Może być wykorzystywany w każdej praktyce stomatologicznej, jest bardzo prosty w obsłudze, nie wymaga specjalistycznego podłoża, warunków oraz sprzętu laboratoryjnego. Ponadto czas odczytu testu, dokonany „gołym okiem", wynosi $15 \mathrm{~min}$.

\section{Wniosek}

Test Saliva Check Mutans wydaje się być testem przydatnym, pozwalającym klinicyście na ocenę poziomu drobnoustrojów próchnicotwórczych celem określenia ryzyka próchnicy. Może być również wykorzystywany w edukacji pacjentów w celu zmotywowania ich do poprawy higieny jamy ustnej.

\section{Oświadczenia}

Oświadczenie dotyczące konfliktu interesów

Autorzy deklarują brak konfliktu interesów w autorstwie oraz publikacji pracy.

\section{Źródła finansowania}

Autorzy deklarują brak źródeł finansowania.

\section{Piśmiennictwo}

[1] Ferreira-Nóbilo NP, Tabchoury CP, Sousa Mda L, Cury JA. Knowledge of dental caries and salivary factors related to the disease: influence of the teaching-learning process. Braz Oral Res. 2015;29(1):1-7. Doi.10.1590/1807-3107BOR-2015.vol29.0061.

[2] Leone CW, Oppenheim FG. Physical and chemical aspects of saliva as indicators of risk for dental caries in humans. J Dent Educ. 2001;65(10):1054-1062. Doi.10.1002/j.0022-0337.2001.65.10.tb03449.x

[3] Lange DE, Plagmann HC, Eenboom A, Promsberger A. Klinische Bewertungsverfahren zur Objektivierung der Mundhygiene. Dtsch Zahnärztl Z. 1977;32:44-47.

[4] Ainamo, J, Bay I. Problems and proposals for recording gingivitis and plaque. Int Dent J. 1975;25:229235.

[5] Lang NP, Tonetti MS. Oral Health Prev Dent. Periodontal risk assessment (PRA) for patients in supportive periodontal therapy (SPT). Periodontology 2000. 2003;7-16.

[6] Marsh PD. Dental plaque as a biofilm and a microbial community - implications for health and disease. BMC Oral Health. 2006;6:14. Doi.10.1186/14726831-6-S1-S14.

[7] Simón-Soro A, Mira A. Solving the etiology of dental caries. Trends Microbiol. 2015;23(2):76-82. Doi.10.1016/j.tim.2014.10.010.

[8] Wennerholm K, Emilson CG. Comparison of Saliva-Check Mutans and Saliva-Check IgA Mutans with the Cariogram for caries risk assessment. Eur J Oral Sci. 2013;121:389-393. Doi.10.1111/eos.12069.

[9] Gao XL, Seneviratne CJ, Lo EC, Chu CH, Samaranayake LP. Novel and conventional assays in determining abundance of Streptococcus mutans in saliva. Int J Paediatr Dent. 2012;22:363-368. Doi.10.1111/ j.1365-263X.2011.01207.x.

[10] Fontana M, Zero DT. Assessing patients' caries risk. J Am Dent Assoc. 2006;137:1231-1239. Doi.10.14219/ jada.archive.2006.0380.

[11] Singh S, Sharma A, Sood PB, Sood A, Zaidi I, Sinha A. Saliva as a prediction tool for dental caries: An in vivo study. J Oral Biol Craniofac Res. 2015;5(2):5964. Doi.10.1016/j.jobcr.2015.05.001.

[12] Saravia ME, Silva LA, Silva RA, et al. Evaluation of Chair-Side Assays in High Microbiological Caries-Risk Subjects. Braz Dent J 2015;26(6):592-595. Doi.10.1590/0103-6440201300389.

Zaakceptowano do edycji: 2020-06-01 Zaakceptowano do publikacji: 2020-06-15

Adres do korespondencji:

Tamara Pawlaczyk-Kamieńska

Zakład Stomatologii Grup Ryzyka

Katedra Stomatologii Dziecięcej

Uniwersytet Medyczny im. Karola Marcinkowskiego

w Poznaniu

e-mail: tpawlaczyk@ump.edu.pl 